九州大学学術情報リポジトリ

Kyushu University Institutional Repository

\title{
Analysis of Carbon Dioxide Solubility Increasement Caused by Baffle Diameter Variation in Airlift Photobioreactor to Growth Rate of Synechococcus HS-9 Biomass
}

Sulthan Rafi i Ardiansyah

Department of Biology, Faculty of Mathematics and Natural Sciences, Universitas Indonesia

Nasruddin

Department of Mechanical Engineering, Faculty of Engineering, Universitas Indonesia

Sjamsuridzal, Wellyzar

Department of Biology, Faculty of Mathematics and Natural Sciences, Universitas Indonesia

Wardhana, Wisnu

Department of Biology, Faculty of Mathematics and Natural Sciences, Universitas Indonesia 他

https://doi.org/10.5109/4742136

出版情報 : Evergreen. 8 (4)，pp.879-884，2021-12. Transdisciplinary Research and Education Center for Green Technologies, Kyushu University

バージョン :

権利関係 : 


\title{
Analysis of Carbon Dioxide Solubility Increasement Caused by Baffle Diameter Variation in Airlift Photobioreactor to Growth Rate of Synechococcus HS-9 Biomass
}

\author{
Sulthan Rafii Ardiansyah ${ }^{1}$, Nasruddin ${ }^{2}$, Wellyzar Sjamsuridzal ${ }^{1}$, Wisnu Wardhana ${ }^{1}$ \\ and Nining Betawati Prihantini ${ }^{1, *}$ \\ ${ }^{1}$ Department of Biology, Faculty of Mathematics and Natural Sciences, Universitas Indonesia, Kampus UI \\ Depok 16424, Depok, Indonesia \\ ${ }^{2}$ Department of Mechanical Engineering, Faculty of Engineering, Universitas Indonesia, Kampus UI \\ Depok 16424, Depok, Indonesia
}

*Author to whom correspondence should be addressed:

E-mail: nining.prihantini@gmail.com; nining@sci.ui.ac.id

(Received April 30, 2021; Revised December 16, 2021; accepted December 16, 2021).

\begin{abstract}
Photobioreactor (PBR) have been one of the most popular system that used for multiplying microalgal biomass. Many researches have been conducted to develop photobioreactor that suit the most with prominent microalgae strains. Carbon dioxide supply is one of many sectors that play an important role for growing microalgae. Carbon dioxide are used by the microalgal cells to produce many chemical compounds that support growth. In many cases, carbon dioxide must be solved into growth media to be utilized by the cells. This research focused on analyzing the effect of carbon dioxide solubility increasement caused by variation of baffle in airlift photobioreactor (APBR) to growth rate of Synechococcus HS-9 biomass. Twenty-one day of experiment resulting that there are growth rate differences occurs. The highest growth rate occurs in APBR-A, APBR-B, and control PBR are $0.515,0.463$, and 0.738 respectively. Despite of the maximum growth rate occurred, there are fluctuation of growth rate happen during experiment. Carbon dioxide solubility test then conducted to see effect of baffle variation. The best carbon dioxide solubility occurred in APBR-B with $23 \mathrm{mg} / \mathrm{L}$, then followed by APBR-A with $22 \mathrm{mg} / \mathrm{L}$, and control PBR with $20 \mathrm{mg} / \mathrm{L}$ after 24 hours of treatment. Further analysis resulting that there is no strong correlation between carbon dioxide solubility increasement to growth rate of Synechococcus HS-9 biomass. This occurred due degression of acidity value $(\mathrm{pH})$ caused by excess of carbonic acid formed by carbon dioxides who diluted into growth media.
\end{abstract}

Keywords: Carbon dioxide; Growth Rate; Photobioreactor, Solubility; Synechococcus HS-9

\section{Introduction and background}

Energy is one of the most important things that support human lives. Human nowadays are exploiting nonrenewable energy resources to maintain their activities ${ }^{1}$. In order to maintain energy sustainability, sustainable development goals (SDG) stated that we need to achieve affordable and clean energy for our future ${ }^{2}$. This goal can be achieved by change our old energy resources to the renewable energy resources ${ }^{3}$ ) One of many types of renewable energy resources came from utilizing microalgae biomass. Prokaryotic microalgae (cyanobacteria) is a type of microalgae that has the potential to be used as a renewable energy source. This is because they can produce lipids properly. Examples of potential cyanobacteria are genus Synechococcus ${ }^{4}$ and the genus Leptolyngbia ${ }^{5}$.

Microalgae are photosynthetic microorganism that have contents similarities with plants ${ }^{6}$. This microorganism can produce biochemical substances that can be utilized for developing biofuels ${ }^{7}$. The biochemical substances occurred in microalgae are carbohydrates, lipid, and protein $^{3)}$. Carbohydrates and lipid extracted from microalgae bodies, later can be derived into many kinds of biofuels such as biodiesel and bioethanol ${ }^{7}$. Microalgae utilized photon from light sources and turn it into biochemical substances through photosynthesis. The waste product of this mechanism is oxygen that later can 
be accumulated in the atmosphere and utilized by other organisms $^{8)}$. Based on that ability, microalgae can be a good chance to be used to achieve affordable and clean energy resources.

Utilization of microalgae as biofuel feedstock need a lot of biomass. To achieve that, many researchers are conducting experiment to develop optimum system for growing microalgae biomass. The system used for multiplying microalgae biomass is photobioreactor $(\mathrm{PBR})^{9}$. One type of photobioreactor that is commonly used to increase microalgae biomass is the bubble column photobioreactor (BCPBR). This type of photobioreactor is commonly used because of its slim shape, so that the use of area for the photobioreactor is more efficient than other types of photobioreactors ${ }^{10}$. Controlled factors in the system include the availability of nutrients, light, temperature, acidity $(\mathrm{pH})$ and air ${ }^{11)}$. The combination of all these factors affects the quantity and quality of biomass produced. The determination of the combination of all the factors above is carried out specifically for the microalgae used, so that the development of a photobioreactor system needs to pay attention to the type of microalgae used.

To develop optimum PBR system for microalgae, several factors must be researched. These factors are light intensity, temperature, nutrition, acidity, and gas supply ${ }^{12)}$. One of the most important factors to be researched is gas supply. Microalgae used carbon dioxide $\left(\mathrm{CO}_{2}\right)$ to be carbon sources for producing biochemical substances. Microalgae usually utilized dissolved $\mathrm{CO}_{2}$ and absorb it into their cell ${ }^{13)}$. Higher amount of dissolved $\mathrm{CO}_{2}$ mean that more carbon can be utilized by the cells. In order to increase $\mathrm{CO}_{2}$ solubility, physical modification of PBR system such as baffle addition can be conducted. Addition of baffle is increasing $\mathrm{CO}_{2}$ residence time ${ }^{14)}$. It means $\mathrm{CO}_{2}$ injected to the system had more time to react with water and dissolved.

Optimal gas solubility can be obtained by adjusting the current pattern in the photobioreactor system. The optimization process is carried out by adding a baffle component ${ }^{10)}$. The addition of these components causes the conventional BCPBR system to be modified into an airlift photobioreactor (APBR).

Synechococcus HS-9 is used in this research as biological agent for microalgae biomass production. This kind of microalgae is indigenous cyanobacteria isolated from Rawa Danau hot spring in Banten, Indonesia ${ }^{15)}$. Synechococcus has round (coccoid) with a size ranging from 0.5-2.5 $\mu^{16)}$. Synechococcus HS-9 is known to contain fatty acids which can potentially be used as biodiesel agents ${ }^{17)}$. The strain was chosen because it can be multiplied rapidly and their ability in extreme area ${ }^{18)}$. The biochemical substances contained inside the cells also abundant to be used as biofuel feedstock ${ }^{19}$. This research aim is to analyze effect of $\mathrm{CO}_{2}$ solubility increasement impact to growth rate of Synechococcus HS-9 biomass.

\section{Method and experimental setup}

There are several steps in this research. The research scheme can be seen in figure 1. The first step is the PBR system preparation. There are nine units of PBR used in this research (figure 2). These nine units of PBR are consists of three variation with three time of replications. The first system is bubble column photobioreactor (BCPBR) as control. Second and third system is airlift photobioreactor (APBR) with baffle diameter variations. Variations conducted in APBR system are $6 \mathrm{~cm}$ and $8 \mathrm{~cm}$. All of the PBR system was assembled according to the design in figure 3 , and figure 4 , meanwhile figure 5 describing diameter of baffle variations.

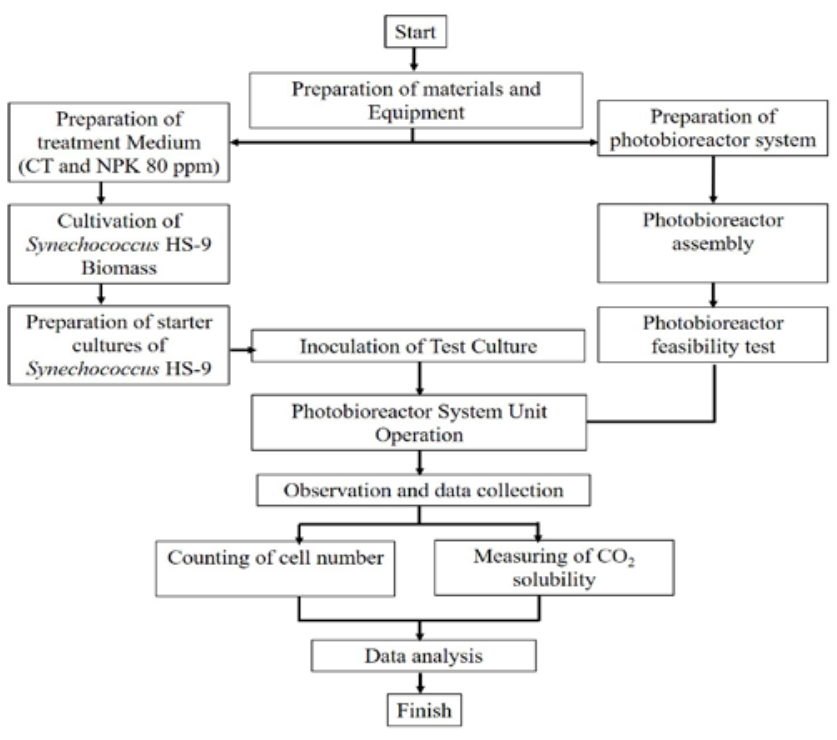

Fig. 1: The research scheme

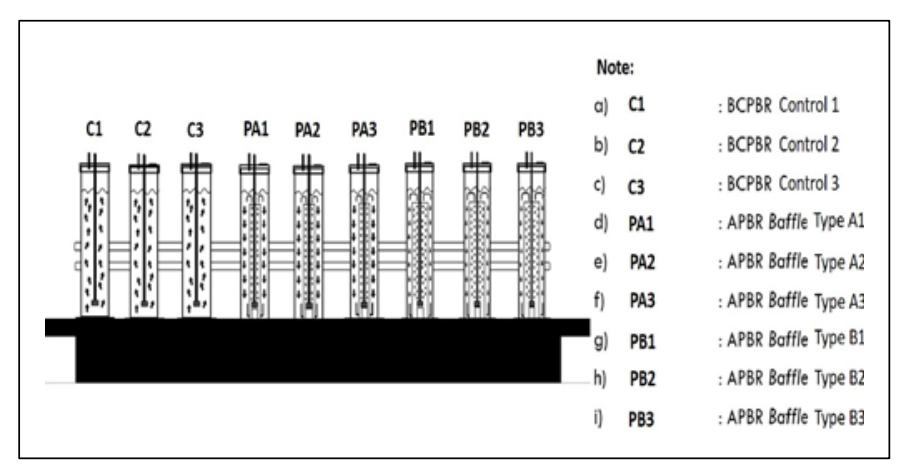

Fig. 2: The nine units of PBR: three BCPBR for control; three APBR type A; three APBR type B 


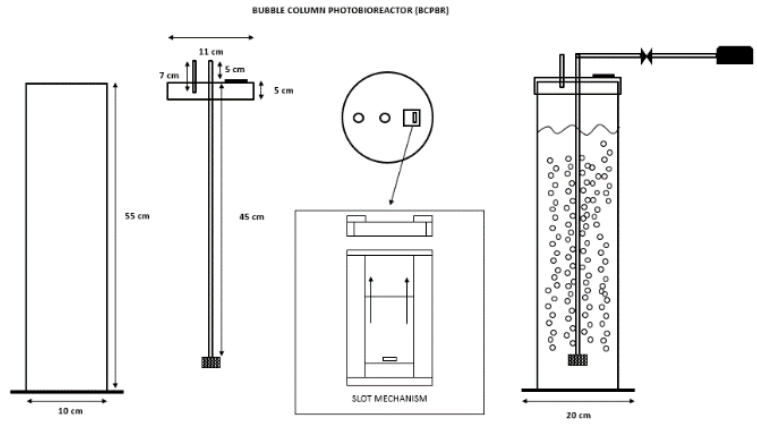

Fig. 3: The design of bubble column photobioreactor (BCPBR)

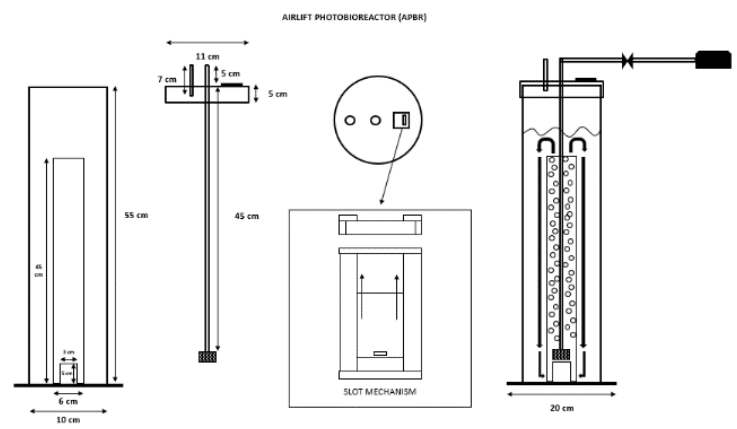

Fig. 4: The design of airlift photobioreactor (APBR)
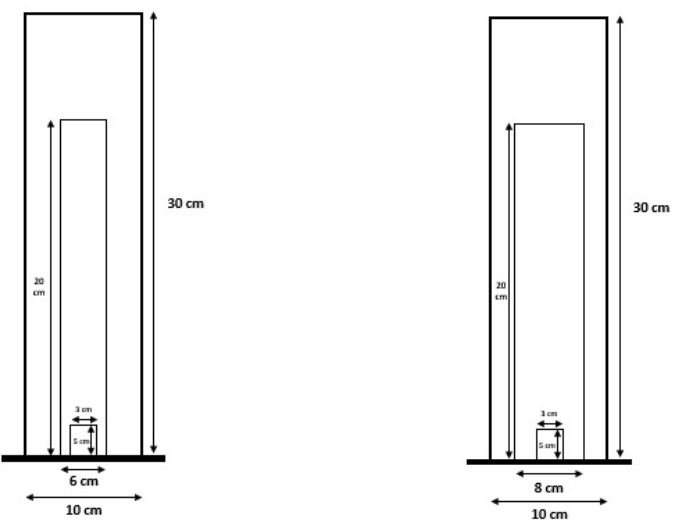

Fig. 5: Diameter (Ø) variations of baffle (APBR A (left): 6 cm; APBR B (right): $8 \mathrm{~cm}$ )

The Synechococcus HS-9 biomass later was cultivated into NPK 80 ppm growth media with acidity number $(\mathrm{pH})$ 6.5 and then incubated inside the system $^{20)}$. The observation was conducted for 21 days. Data collections including Synechococcus HS-9 cell number and $\mathrm{CO}_{2}$ solubility. Cell number acquired in this research then processed into growth rate through this formula $1^{11)}$.

$$
r=\frac{\ln N t-\ln N 0}{\Delta t}
$$

Carbon dioxide $\left(\mathrm{CO}_{2}\right)$ solubility was measured using titration methods. NPK 80 ppm media was treated inside the PBR system for 4 hours and 24 hours. Later the growth media was sampled and measured by using $\mathrm{Na}_{2} \mathrm{CO}_{3} 0.045$ $\mathrm{N}$ and phenolphthalein (PP). Data acquired then processed into this formula $2^{21)}$.

$$
\text { mg. } L^{-1} \mathrm{CO}_{2}=\frac{1000}{v} \times p \times 0,5
$$

Later, all of the acquired data will be accumulated and processed into table and graph.

\section{Results and Discussion}

\subsection{Analysis of carbon dioxide $\left(\mathrm{CO}_{2}\right)$ solubility}

Carbon dioxide $\left(\mathrm{CO}_{2}\right)$ solubility was measured by using titration methods. Data acquired in this step include $\mathrm{CO}_{2}$ solubility in distilled water and NPK 80 ppm growth media after 0 hours, 4 hours, 24 hours, and NPK 80 ppm with Synechococcus HS-9 inside it. All of the parameters measured from all three types of PBR systems. Results of this step are described in table 1.

Table 1־ $\mathrm{CO}_{2}$ solubility inside PBR systems (ØAPBR A: 6 cm; ØAPBR B: 8 cm)

\begin{tabular}{|l|c|}
\hline \multicolumn{1}{|c|}{ Parameters } & $\begin{array}{c}\mathbf{C O}_{2} \text { solubility } \\
\text { (mg/L) }\end{array}$ \\
\hline Distilled Water & 8 \\
\hline NPK 80 ppm & 10 \\
\hline NPK 80 ppm BCPBR (4 hours) & 13 \\
\hline NPK 80 ppm BCPBR (24 hours) & 20 \\
\hline NPK 80 ppm BCPBR + Synechococcus & 15 \\
\hline NPK 80 ppm APBR A (4 hours) & 20 \\
\hline NPK 80 ppm APBR A (24 hours) & 22 \\
\hline NPK 80 ppm APBR A + Synechococcus & 17 \\
\hline NPK 80 ppm APBR B (4 hours) & 21 \\
\hline NPK 80 ppm APBR B (24 hours) & 23 \\
\hline NPK 80 ppm APBR B + Synechococcus & 19 \\
\hline
\end{tabular}

Based on the results, data shown that $\mathrm{CO}_{2}$ solubility inside distilled water and normal NPK 80 ppm are $8 \mathrm{mg} / \mathrm{L}$ and $10 \mathrm{mg} / \mathrm{L}$ respectively. Meanwhile, the highest $\mathrm{CO}_{2}$ solubility in BCPBR $20 \mathrm{mg} / \mathrm{L}$ after 24 hours, APBR A was $22 \mathrm{mg} / \mathrm{L}$ after 24 hours and APBR B was $23 \mathrm{mg} / \mathrm{L}$ after 24 hours. As we see in the results, $\mathrm{CO}_{2}$ solubility increase progressively from the normal $\mathrm{CO}_{2}$ solubility to maximum $\mathrm{CO}_{2}$ solubility. This result was influenced by addition of baffle inside APBR system. Baffle inside APBR system create two zones with different pressure ${ }^{22}$. The zone was down comer and upriser. Zone created inside the system created flow pattern as seen in figure 6 . 


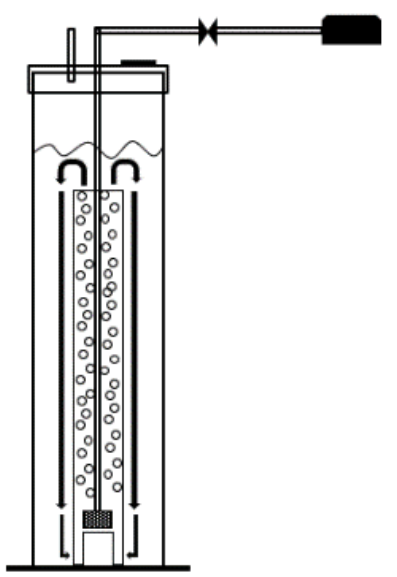

Fig. 6: Illustration of gas flow pattern inside APBR system

Pressure in down comer area was low meanwhile in upriser was high. This different pressure influencing the $\mathrm{CO}_{2}$ residence time inside APBR system ${ }^{23}$. Air bubble injected from inlet will have more time to react with water and the $\mathrm{CO}_{2}$ will turn into carbonic acid $\left(\mathrm{HCO}_{3}{ }^{-}\right.$) (soluble form). The $\mathrm{HCO}_{3}{ }^{-}$later will be utilized by Synechococcus HS-9 cells for photosynthesis and used for many metabolism pathways ${ }^{24)}$.

\subsection{Analysis of Synechococcus HS-9 growth rate}

Increasement of $\mathrm{CO}_{2}$ solubility affect several things inside the system. These changes were affecting the Synechococcus HS-9 biomass growth. Based on 21 days of observations, the growth curve was obtained. After analyzing the growth curve, log phase of Synechococcus HS-9 was determined and analyzed. The log phase was occurred for 5 days with four intervals. Later, the data acquired from growth curve was processed using formula (1). Result of analysis was shown in figure 7.

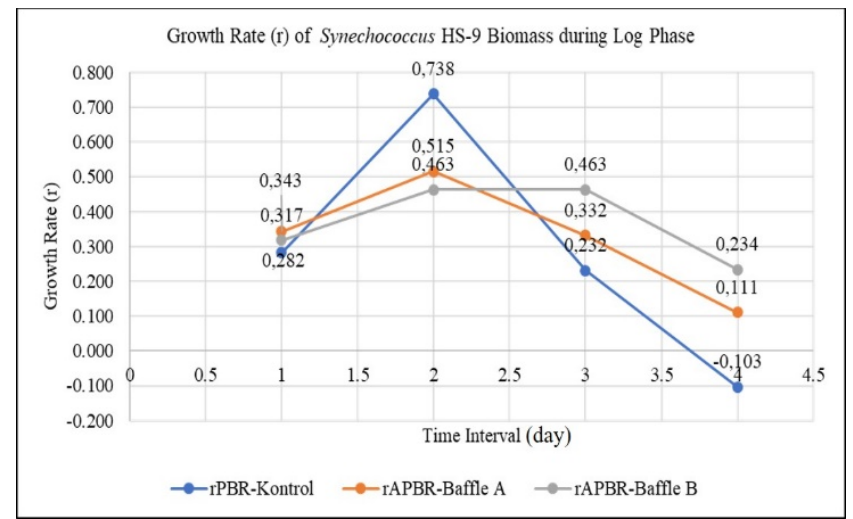

Fig. 7: Growth rate ( $r$ ) of Synechococcus HS-9 during Log Phase

Based on the result shown, the growth rate of Synechococcus HS-9 in 4 four days of log phase was fluctuated. First interval (T0-T1) and second interval (T1T2) shown increasement of growth rate. Meanwhile, third interval (T2-T3) and fourth interval (T3-T4) shown decreasing of growth rate. Data also shown the highest growth rate for BCPBR and APBR A occurred in the second interval (T1-T2) with 0.738 per day and 0.515 per day respectively. Meanwhile the highest growth rate of APBR B occurred in third interval (T2-T3) with number of 0.463 per day.

Based on results, fluctuation of Synechococcus HS-9 biomass growth rate was influenced directly by $\mathrm{CO}_{2}$ reaction inside PBR system. Carbonic acid $\left(\mathrm{H}_{2} \mathrm{CO}_{3}\right)$ formed inside system are higher than normal system. This phenomenon causing the cells can absorb adequate carbon for their metabolism. Cyanobacteria utilize $\mathrm{CO}_{2}$ gas as a raw material for glucose anabolism to produce energy. To use $\mathrm{CO}_{2}$, cyanobacteria cells need to move $\mathrm{CO}_{2}$ from the environment into the body ${ }^{25}$. The transfer process is carried out through various types of different $\mathrm{Ci}$ transporters. $\mathrm{CO} 2$ gas in liquid media dissolves in the form of $\mathrm{HCO}_{3}{ }^{-}$according to the existing equilibrium reaction. Cyanobacteria cells have ability to absorb $\mathrm{CO}_{2}$ gas both in gaseous and dissolved form $\left(\mathrm{HCO}_{3}^{-}\right)^{23)}$. The ability of cells to absorb these two forms of $\mathrm{CO}_{2}$ differs depending on the $\mathrm{Ci}$ transporter and the rubisco formation they have.

Synechococcus is a $\beta$-cyanobacteria with $5 \mathrm{Ci}$ transporters and $1 \mathrm{~B}$ rubisco ${ }^{24)}$. The cyanobacteria group tends to utilize carbon dioxide in the form of $\mathrm{HCO}_{3}$ compared to $\mathrm{CO}_{2}$ in the form of gas. This is due to the $\mathrm{Ci}$ transporter for the removal of $\mathrm{HCO}_{3}{ }^{-}$does not require energy (passive), while the $\mathrm{Ci}$ transporter $\mathrm{CO}_{2}$ requires energy and $\mathrm{CO}_{2}$ that has been absorbed needs to be converted into $\mathrm{HCO}_{3}{ }^{-}$before it can be utilized. Carbon dioxide that has entered the cell body is then transferred to the carboxisome and converted back into $\mathrm{CO}_{2}$ by the enzyme carbonyx anhydrase (CA) before it is converted to phosphoglyceric acid (PGA) by rubisco $1 \mathrm{~B}^{25)}$.

For short amount of time, increasement of $\mathrm{CO}_{2}$ solubility can uplift growth rate of Synechococcus HS-9 biomass. Meanwhile after that, the growth rate started to fluctuate and even drop. This is happened because process of dissolving carbon dioxide (CO2) gas into carbonate compounds $\left(\mathrm{HCO}_{3}{ }^{-}\right)$and carbonic acid $\left(\mathrm{H}_{2} \mathrm{CO}_{3}\right)$ causes a decrease in the acidity $(\mathrm{pH})$ of the PBR system ${ }^{26}$. The phenomenon then affects many things one of them, namely photosynthetic disorders due to disruption of the nutrient transport process and inhibited metabolic activity $^{27)}$. In addition, the phenomenon of photodamage also influences the process of cell photosynthesis in the PBR system. In summary, the process of photosynthesis has the role of producing intermediate compounds in the form of acetyl-CoA. These compounds then play a role in forming derivative compounds such as nucleotide acids, amino acids, lipids, energy (ATP), and several other components ${ }^{28}$. All of these metabolites play a role in the life and reproduction process of Synechococcus HS-9 cells, so photosynthetic disorders can cause a gradual decrease in the quality and quantity of cells. 


\section{Conclusions}

The increasement of carbon dioxide $\left(\mathrm{CO}_{2}\right)$ solubility is affecting growth rate of Synechococcus HS-9 biomass specially during log phase. During 4 days of log phase, the growth rate was fluctuated from rising to fall of growth rate. This is happened because addition of baffle inside APBR system are increasing residence time of $\mathrm{CO}_{2}$ to react with the growth media. The highest $\mathrm{CO}_{2}$ solubility occurred in BCPBR, APBR A, and APBR B after 24 hours with $20 \mathrm{mg} / \mathrm{L}, 22 \mathrm{mg} / \mathrm{L}$, and $23 \mathrm{mg} / \mathrm{L}$ respectively. Dissolving process of $\mathrm{CO}_{2}$ into $\mathrm{HCO}_{3}{ }^{-}$causing decrease of acidity and affecting the metabolism process. So, in further research, acidities buffer research must be conducted in order to maintain stable acidity value $(\mathrm{pH})$.

\section{Acknowledgements}

This research was funded by Penelitian Dasar Unggulan Perguruan Tinggi Grant (PDUPT) by Ministry of Research and High Education (Kemenristek Dikti) Fiscal Year of 2019 to Dr. Nining Betawati Prihantini, M.Sc. with grant no. NKB1605/UN2.R3.1/HKP.05.00/2019.

\section{Nomenclature}

$\begin{array}{ll}\text { pH } & \text { Power of hydrogen } \\ \text { PBR } & \text { Photobioreactor } \\ \text { HS-9 } & \text { Hot spring number 9 } \\ \text { SDG } & \text { Sustainable development goals } \\ \text { BCPBR } & \text { Bubble column photobioreactor } \\ \text { APBR } & \text { Airlift photobioreactor } \\ r & \text { Specific growth rate } \\ m g . L^{-1} & \text { Milligram per liter } \\ \varnothing & \text { Diameter of baffle } \\ v & \text { Volume of sample } \\ p & \text { Titrant coefficient } \\ \text { NPK } & \text { Nitrogen phosphorous potassium } \\ \mathrm{HCO}{ }^{-} & \text {Soluble carbonic acid } \\ \mathrm{H}_{2} \mathrm{CO}_{3} & \text { Carbonic acid } \\ \mathrm{Ci} & \text { Carbon inorganic } \\ \mathrm{CA} & \text { Carbonyx anhydrase } \\ \mathrm{PGA} & \text { Phospoglyseric acid } \\ \text { ATP } & \text { Adenosine triphosphate } \\ A c e t y l-C o A & \text { Acetyl coenzyme A } \\ l n & \text { Natural logarithm } \\ N t & \text { Cell numbers in certain time } \\ N 0 & \text { Cell numbers in first time } \\ \Delta t & \text { Time interval } \\ & \end{array}$

\section{References}

1) M. K. Barai, and B. B. Saha. Energy Security and
Sustainability in Japan. EVERGREEN Joint Journal of Novel Carbon Resource Sciences \& Green Asia Strategy 2 (1). 49-56 (2015).

2) E. B. Barbier, and J. C. Burgess, "The Sustainable Development Goals and The Systems Approach to Sustainability", Economics., 11 1-23 (2017). http://dx.doi.org/10.5018/economicsejournal.ja.2017-28.

3) A. Kuncoro, and W. W. Purwanto. Analysis of Energy-Water Nexus Palm Oil Biodiesel Production in Riau Using Life Cycle Assessment and Water Footprint Methods. EVERGREEN Joint Journal of Novel Carbon Resource Sciences \& Green Asia Strategy 7 (1) 104-110 (2020).

4) A. Rahman, N. B. Prihantini, and Nasruddin. Biomass Production and Synthesis of Biodiesel from Microalgae Synechococcus HS-9 (Cyanobacteria) Cultivated Using Bubble Column Photobioreactors. EVERGREEN Joint Journal of Novel Carbon Resource Sciences \& Green Asia Strategy 7 (4). 564570 (2020).

5) N. B. Prihantini, N. Rakhmayanti, S. Handayani, W. Sjamsuridzal, W. Wardhana, and Nasruddin. Biomass Production of Indonesian Indigenous Leptolyngbya Strain on NPK Fertilizer Medium and its Potential as a Source of Biofuel. EVERGREEN Joint Journal of Novel Carbon Resource Sciences \& Green Asia Strategy 7 (4). 593-601 (2020).

6) E.G. Bellinger, and D.C. Sigee, "Freshwater Algae: Identification, enumeration and use as bioindicators: Second edition,” Wiley, 292 (2015). doi:10.1002/9781118917152.

7) A. Ugurlu, and S. Oztuna, "A comparative analysis study of alternative energy sources for automobiles," Int. J. Hydrogen Energy, 40 (34) 11178-11188 (2015). doi:10.1016/j.ijhydene.2015.02.115.

8) A. Lehmuskero, M. Skogen Chauton, and T. Boström, "Light and photosynthetic microalgae: a review of cellular- and molecular-scale optical processes,” Prog. $\begin{array}{llll}\text { Oceanogr., } & 168 & 43-56 & \text { (2018). }\end{array}$ doi:10.1016/j.pocean.2018.09.002.

9) S.R. Ardiansyah, A.M. Orlando, A. Rahman, N.B. Prihantini, and Nasruddin, "Effect of aeration in simple photobioreactor system for biomass production of synechococcus sp. (cyanobacteria) -7 and hs-9 as biofuel feedstock," E3S Web Conf., 67 02006 (2018). doi:10.1051/e3sconf/20186702006.

10) E. Molina, J. Fernández., F. G. Acién, and Y. Chisti, “Tubular Photobioreactor Design for Algal Cultures”, Journal of Biotechnology 92: 113-131 ( 2001).

11) R. A. Andersen. Algal culturing techniques. Elsevier academic press. Hong kong: ix + 565 (2005).

12) R.N. Singh, and S. Sharma, "Development of suitable photobioreactor for algae production - a review," Renew. Sustain. Energy Rev., 16 (4) 2347-2353 (2012). doi:10.1016/j.rser.2012.01.026.

13) R. Slade, and A. Bauen, "Micro-algae cultivation for biofuels: cost, energy balance, environmental impacts 
and future prospects,” Biomass and Bioenergy, $53(0)$ 29-38 (2013). doi:10.1016/j.biombioe.2012.12.019.

14) N. Bouakaz, Zoubida Bendjama, Adh'ya-Eddine Hamitouche, Abdeltif Amrane, and M. Trari, "Effect of inclination angle of baffled reactor at up-flow on residence time distribution," Arab. J. Sci. Eng., 43 5723-5731 (2018). doi:10.1007/s13369-017-2935-y.

15) N. B. Prihantini. Polyphasic Taxonomy of Culturable Cyanobacteria Isolated from Hot Springs in West Java, Indonesia. Dissertation Department of Biology, Faculty of Mathematics and Natural Sciences, Depok, p. 115. (2015).

16) J. D. Wehr, and R. G. Sheath. Freshwater Algae of North America. Academic Press Publisher. California USA, p. 897. (2003.)

17) N.B. Prihantini, S. Handayani, W. Sjamsuridzal, A. Yokota, and Nasruddin, "Fatty acid characterization of indigenous cyanobacterial strains isolated from five hot springs in indonesia,” E3S Web Conf., 67 02021 (2018). doi:10.1051/e3sconf/20186702021.

18) J. Jezberová, and J. Komárková, “Morphometry and growth of three Synechococcus-like picoplanktic cyanobacteria at different culture conditions," in: Hydrobiologia, (2007). doi:10.1007/s10750-0060429-0.

19) M.K. Lam, and K.T. Lee, "Microalgae biofuels: a critical review of issues, problems and the way forward," Biotechnol. Adv., 30 (3) 673-690 (2012). doi:10.1016/J.BIOTECHADV.2011.11.008.

20) S.R. Ardiansyah, A. M. Orlando, A.Rahman, N. B. Prihantini, and Nasruddin. Tubular Photobioreactor: A Preliminary Experiment Using Synechococcus sp. (Cyanobacteria) Cultivated in NPK Media for Biomass Production as Biofuel Feedstock. EVERGREEN Joint Journal of Novel Carbon Resource Sciences \& Green Asia Strategy 6 (2).157161 (2019).

21) I. B. Prasetyawan, L. Maslukah, and A. Rifai. "Pengukuran Sistem Karbon Dioksida (CO2) Sebagai Data Dasar Penentuan Fluks Karbon di Perairan Jepara". Buletin Oseanografi Marina 6 (1) 9-16 (2017).

22) B.D. Fernandes, A. Mota, A. Ferreira, G. Dragone, J.A. Teixeira, and A.A. Vicente, "Characterization of split cylinder airlift photobioreactors for efficient microalgae cultivation,” Chem. Eng. Sci., 117 445454 (2014). doi:10.1016/j.ces.2014.06.043.

23) B.D. Rae, B.M. Long, M.R. Badger, and G.D. Price, "Functions, compositions, and evolution of the two types of carboxysomes: polyhedral microcompartments that facilitate co2 fixation in cyanobacteria and some proteobacteria," Microbiol. Mol. Biol. Rev., 77 (3) 357-379 (2013). doi:10.1128/MMBR.00061-12.

24) R. Yan, D. Zhu, Z. Zhang, Q. Zeng, and J. Chu, "Carbon metabolism and energy conversion of synechococcus sp. pcc 7942 under mixotrophic conditions: comparison with photoautotrophic condition,” J. Appl. Phycol., 24 (4) 657-668 (2012). doi:10.1007/s10811-011-9683-2.

25) M.R. Badger, G.D. Price, B.M. Long, and F.J. Woodger, "The environmental plasticity and ecological genomics of the cyanobacterial co2 concentrating mechanism,” J. Exp. Bot., 57 (2 SPEC. ISS.) 249-265 (2006). doi:10.1093/jxb/eri286.

26) G. Markou, D. Vandamme, and K. Muylaert, "Microalgal and cyanobacterial cultivation: the supply of nutrients,” Water Res., 65 186-202 (2014). doi:10.1016/j.watres.2014.07.025.

27) M. Drath, N. Kloft, A. Batschauer, K. Marin, J. Novak, \& K. Forchhammer "Ammonia Triggers Photodamage of Photosystem II in the Cyanobacterium Synechocystis sp. Strain PCC 68031". Plant Physiology 147: 206-215,(2008).

28) U. Towijit, N. Songruk, P. Lindblad, A. Incharoensakdi, and S. Jantaro, "Co-overexpression of native phospholipid-biosynthetic genes plsx and plsc enhances lipid production in synechocystis sp. pcc 6803,” Sci. Rep., (n.d.). doi:10.1038/s41598-01831789-5 